This is a self-archived - parallel published version of this article in the publication archive of the University of Vaasa. It might differ from the original.

\title{
Impact of distributed generation on protection and voltage regulation of distribution systems : a review
}

\author{
Authors: Razavi, Seyed-Ehsan; Rahimi, Ehsan; Javadi, Mohammad \\ Sadegh; Nezhad, Ali Esmaeel; Lotfi, Mohamed; Shafie-khah, \\ Miadreza; Catalãode, João P.S. \\ Title: Impact of distributed generation on protection and voltage \\ regulation of distribution systems : a review \\ Year: $\quad 2019$ \\ Version: Accepted manuscript \\ Copyright Elsevier, Creative Commons Attribution Non-Commercial No \\ Derivatives License
}

\section{Please cite the original version:}

Razavi, Seyed-Ehsan; Rahimi, Ehsan; Javadi, Mohammad Sadegh; Nezhad, Ali Esmaeel; Lotfi, Mohamed; Shafie-khah, Miadreza; Catalãode, João P.S. (2019). Impact of distributed generation on protection and voltage regulation of distribution systems : a review. Renewable and sustainable energy reviews, 105, 157-167. https://doi.org/10.1016/j.rser.2019.01.050 


\title{
Impact of Distributed Generation on Protection and Voltage Regulation of Distribution Systems: A Review
}

\author{
Seyed-Ehsan Razavi ${ }^{1}$, Ehsan Rahimi ${ }^{2}$, Mohammad Sadegh Javadi ${ }^{2}$, Ali Esmaeel Nezhad ${ }^{3, *}$, \\ Mohamed Lotfi ${ }^{4,5}$, Miadreza Shafie-khah ${ }^{4,6}$, João P. S. Catalão ${ }^{4,5,}{ }^{*}$ \\ ${ }^{I}$ Department of Electrical and Computer Engineering, University of Birjand, Birjand, Iran \\ ${ }^{2}$ Young Researchers and Elite Club, Shiraz Branch, Islamic Azad University, Shiraz, Iran \\ ${ }^{3}$ Department of Electrical, Electronic, and Information Engineering, University of Bologna, Italy \\ ${ }^{4}$ INESC TEC, 4200-465 Porto, Portugal \\ ${ }^{5}$ Faculty of Engineering of the University of Porto, 4200-465 Porto, Portugal \\ ${ }^{6}$ School of Technology and Innovations, University of Vaasa, 65200 Vaasa, Finland
}

\begin{abstract}
During recent decades with the power system restructuring process, centralized energy sources are being replaced with decentralized ones. This phenomenon has resulted in a novel concept in electric power systems, particularly in distribution systems, known as Distributed Generation (DG). On one hand, utilizing DG is important for secure power generation and reducing power losses. On the other hand, widespread use of such technologies introduces new challenges to power systems such as their optimal location, protection devices' settings, voltage regulation, and Power Quality (PQ) issues. Another key point which needs to be considered relates to specific DG technologies based on Renewable Energy Sources (RESs), such as wind and solar, due to their uncertain power generation. In this regard, this paper provides a comprehensive review of different types of DG and investigates the newly emerging challenges arising in the presence of DG in electrical grids.
\end{abstract}

Keywords: Distributed Generation; voltage regulation; protection coordination; uncertainty.

\section{Word Count: 7990}

* Corresponding authors: Ali Esmaeel Nezhad (ali.esmaeelnezhad@gmail.com), at the Department of Electrical, Electronic, and Information Engineering, University of Bologna, Italy, and João P. S. Catalão (catalao@ubi.pt), at INESC TEC and the Faculty of Engineering of the University of Porto, 4200-465 Porto, Portugal. 


\section{Abbreviation List}

$\begin{array}{llll}\text { CAES } & \text { Compressed Air Energy Storage } & \text { PCC } & \text { Point of Common Coupling } \\ \text { DER } & \text { Distributed Energy Resources } & \text { PCI } & \text { Protection Coordination Index } \\ \text { DFIG } & \text { Doubly-Fed Induction Generator } & \text { PDS } & \text { Power Delivery System } \\ \text { DG } & \text { Distributed Generation } & \text { PEV } & \text { Plug-in Electric Vehicle } \\ \text { DOCR } & \text { Directional Overcurrent Relay } & \text { PHEV } & \text { Plug-in Hybrid Electric Vehicle } \\ \text { DSM } & \text { Demand-Side Management } & \text { PI } & \text { Proportional-Integral } \\ D-S T A T C O M & \text { Distributed Static Synchronous Compensator } & P Q & \text { Power Quality } \\ \text { ESS } & \text { Energy Storage System } & \text { PV } & \text { Photovoltaic } \\ F C L & \text { Fault Current Limiter } & \text { RES } & \text { Renewable Energy Source } \\ F L D M & \text { Fuzzy Logic Decision Making } & \text { RTU } & \text { Remote Terminal Unit } \\ F R D F T & \text { Fast Recursive Discrete Fourier Transform } & \text { STATCOM } & \text { Static Synchronous Compensator } \\ \text { GPS } & \text { Global Positioning System } & \text { SVC } & \text { Static VAR Compensator } \\ I E D & \text { Intelligent Electronic Device } & \text { SVR } & \text { Static Voltage Regulator } \\ I R E N A & \text { International Renewable Energy Agency } & \text { TPNLP } & \text { Two-Phase Non-Linear Programming } \\ L V & \text { Low Voltage } & \text { V2G } & \text { Vehicle-to-Grid } \\ M V & \text { Medium Voltage } & \text { VR } & \text { Voltage Regulator } \\ \text { NLP } & \text { Non-Linear Programming } & \text { VRB } & \text { Vanadium Redox Battery } \\ \text { OLTC } & \text { On-Load Tap Changer } & \text { VSC } & \text { Voltage Source Convertor }\end{array}$

\section{Nomenclature}

$I_{f s} \quad$ Short-circuit current without DGs

$I_{f_{D G}} \quad$ Fault current of $D G$

Z Impedance

$R \quad$ Index of relays

\section{Introduction}

On a global level, increasing electrical load demand prompted a remarkable rise in electric power generation capacity. Accordingly, such a growing load demand has influenced the economies of developed countries to be inclined towards minimizing the amount of the load curtailment. Besides, as power plants are typically located far from load centers, power losses and voltage drops are high. In this respect, installing Distributed Generation (DG) units near load centers can contribute to solving these issues [1].

Today, the adoption of renewable DG units as appropriate alternatives to conventional power plants will contribute, to a great extent, to supplying the ever-increasing load demand. The total installed capacity from renewable energy sources (RES), globally, has increased from around $2000 \mathrm{GW}$ in 2016 to $2167 \mathrm{GW}$ in 2017 (i.e., 8.3\% increase in one year) [2]. Different types of renewable and non-renewable DG are available, including wind turbines, thermal solar, solar photovoltaic (PV), hydro power, diesel generators, fuel cells, geothermal, and microturbines [3,4]. Different issues such as increasing load demand, energy storage necessities, and climate change concerns have motivated increasing DG installations which can ultimately result in mitigation of green-house gas emissions. 
Employing large DG units in electric power systems can have several shortcomings and negative impacts on voltage control, frequency control, and protection system settings [5-7]. However, various merits of utilizing DG can be listed as follows:

- Power loss reduction due to the proximity of load and generation.

- Considerable reduction of fossil fuel consumption.

- Reduction of green-house gases.

- Long-term deferral of investment in transmission system expansion.

- Power Quality (PQ) improvement using inverter-based DG [8].

- Voltage drop reduction and voltage profile improvement.

- Power system reliability enhancement.

Another advantage of DG is encountered with the failure of a main power source. In this situation, DG can play the backup role for power systems which may promote PQ in distribution systems [9]. Despite the mentioned advantages of DG, inappropriate siting and sizing of the units in distribution systems can give rise to severe technical challenges [10]. These technical challenges would negatively impact voltage reduction, power supply reliability, system stability, assets control, protection system, and undesirable islanding $[4,11]$. DG can also affect economic issues. For example, distribution companies cover a fraction of their costs by selling access to grid connection. By adding DG units to the system, this income would be jeopardized.

Another key point worthy of further attention is increased uncertainty in the presence of DG, which requires the incorporation of an effective and efficient energy management system. In this respect, the uncertainty of DG power output as backup units must be taken into account, since it may be time-variable [11, 12]. DG units are typically located either at points with high load demand or at the end of feeders in radial distribution systems $[6,12]$.

Many factors such as the system topology and DG units' power output uncertainty affect the system features. In radial distribution systems, optimal siting of DGs can enhance the system voltage profile, reduce the feeder's overloading and peak load demand, and decrease gas emissions from the burning of fossil fuels [13]. It is worth mentioning that DG units are employed mainly in distribution systems as a source of flexibility, which means they transform the currently passive networks into active ones. This feature brings many merits to the power system including distribution capacity deferral, reliability enhancement, and flattening of the peak load demand curve [14-16]. The drivers, merits, and problems in the way of renewable DG integration have been previously pointed out in a 2011 review by Zahedi [17].

DG connected to distribution systems affects the fault current and power flow direction. The most significant impact of DG on distribution systems relates to increasing the short-circuit current and contributing to the fault current for downstream faults $[6,18]$. As a result of the fault current increase in 
distribution networks, DG units reduce the contribution of the system's fault current which in turn causes the protection system to be blinded.

DG can cause malfunctioning of protection systems during faults. For instance, if a fault occurs at one of the feeders adjacent to DG units, an undesired tripping command by protection relays may be triggered. As such, it should be noted that the location of DG units in distribution systems (as well as their number and penetration level), highly impacts protection systems $[6,11,18]$.

This paper reviews the role of DG in electrical grids from a technical point of view. Installing DG units simultaneously brings both merits and severe challenges to existing distribution systems, such as reduced losses, improved reliability, and protection system problems. Accordingly, comprehensively investigating the impact of DG on distribution systems is essential in order to make the most of their capabilities while avoiding potential problems. With the increasingly growing trend of installing renewable power generation, particularly at the distribution level, the impact of DG has become far more highlighted than ever [2]. This paper addresses the voltage regulation methods in presence of DG units and their impact on protection systems, besides solutions proposed thus far to associated problems. These issues are of high significance to future power systems, especially in the context of smart grids.

The organization of the present paper is as follows: Section 2 lists and describes different types of DG. Section 3 discusses the impact of DG penetration on distribution systems. Sections 4 and 5 investigate problems faced by protection systems in the presence of DG units and voltage regulation issues, respectively. Finally, Section 6 draws some relevant conclusions.

\section{Different types of DG}

DG is categorized, according to the active and reactive power delivered to the distribution system, into the following groups [19]:

- DG with active power injection only

This type of DG is connected to the distribution system using an appropriate power electronic interface. This includes small-scale DG units which operate at a unity power factor, such as PV, fuel cells, microturbines, and batteries.

- DG with reactive power injection only

DG units of this type operate at a zero power factor, supplying the required reactive power of distribution systems. Synchronous compensators fall under this category.

- DG with active power injection and reactive power absorption 
This type of DG includes induction generators used in wind turbines. Different types of those induction generators with an improved performance exist, such as fixed-speed, variable-speed, and Doubly-Fed Induction Generator (DFIG). They inject active power into the grid while absorbing reactive power.

- DG with active and reactive power injection

This type of DG is based on synchronous machines such as gas turbines and Combined Heat and Power (CHP) units, capable of injecting both active and reactive power into the grid.

The connection of DG units to the grid depends on some key factors [4], which are listed as follows:

- The type(s) of DG in the system.

- The voltage level at which DG units will be connected.

- The generation level that has been previously connected to the grid.

- The electrical robustness of the grid at the connection point.

- The size of DG connected to the grid.

- The grid short-circuit level at the installation point.

It is worth noting that there is a wide range of DG unit size based on the power output, ranging from a few kilowatts to megawatts $[10,12]$.

\section{Different aspects of DG integration}

In order to investigate the impact of DG on electrical distribution systems, different aspects of their integration must first be discussed. In general, several issues associated with DG integration are as follows:

\subsection{Uncertainties of $D G$}

One of the most important features of RES-based DG connected to electrical systems is uncertain power generation. That is to say, the power output of RES-based DG units may vary unpredictably with time. For example, the power output of wind turbines and PVs is highly dependent on weather conditions which are naturally stochastic, and therefore forecasting their power generation can be a difficult task $[12,13,20]$.

Solar power is uncertain due to some uncontrollable factors which are not continuously available. This shortcoming can be compensated to some extent and in some regions using historical data. However, forecasts of solar irradiation are not always accurate and are associated with high inaccuracy. On the other hand, wind power is the most unpredictable RES, with wind power density being temporally variable and unsteady. This results in intermittent, and sometimes rare, utilization of wind DG units in some regions [21]. Such conditions have resulted in the inapplicability of deterministic models. One solution to accommodate this uncertainty is the utilization of probabilistic techniques in generation scheduling problems. Not only does wind power intermittency complicate generation scheduling problems, but it also causes some concerns regarding system security [22]. In between, it is noteworthy that the investment costs 
of renewable energies have been reducing over the recent years making them promising alternatives to other generation technologies.

According to what was projected by the International Renewable Energy Agency (IRENA), the investment cost of onshore wind turbines decreased by $66 \%$ in 2014 compared to 1983 . Moreover, IRENA has predicted that this cost will be further reduced by $12 \%$ by 2025 [23]. The practical solution to mitigate impacts of RES uncertainties is to use some devices in conjunction with DG units. Some of the possible devices capable of functioning as compensators for RES uncertainties can be stated as [22]:

- Pumped-storage units.

- Gridable electric vehicles with the Vehicle-to-Grid (V2G) capability like Plug-in Electric Vehicles (PEVs) and Plug-in Hybrid Electric Vehicles (PHEVs).

- Hybrid wind-solar systems.

- Battery storage devices.

- Diesel generators.

- Compressed-Air Energy Storage (CAES) devices.

\subsection{Advantages of $D G$}

Different aspects of using DG in electrical systems can be discussed from environmental, economic and technical viewpoints [10]. Today, most pollutant emissions stem from using fossil fuels. In this regard, since RES form the major fraction of DG in Germany, Denmark and Sweden [24], and considering the fact that oil reserves are exhausting, employing environmentally-friendly DG units would be promising in the future as a likely way to mitigate climate change [25]. The merits of using DG must first be considered to better understand their economic advantages. The merits of utilizing DG in electrical distribution systems can be briefly stated as follows $[10,26]$ :

- Improved efficiency of the system

- Reduced operating cost due to peak load shaving

- Reduced care investment due to the improved environment

- Reduced maintenance cost

- Reduced investment in the system expansion

- Enhanced protection for significant loads

- Reduced requirements and the associated costs

- Reduced fuel costs

The technical aspects of DG presence in electrical systems can be discussed by taking into account their impacts on different parameters such as power losses, voltage profile, and system reliability. Therefore, it can be declared that siting and sizing of DG units in a non-optimal way would adversely affect the electrical 
system by raising the voltage magnitude and fluctuations, causing harmonics and instability, and also negatively influencing voltage regulation issues [27]. Furthermore, it is worth mentioning that non-optimal siting of DG may lead to non-optimal utilization of those units' capacity [28].

\section{Protection systems in the presence of DGs}

The protection of conventional distribution systems is a straightforward task due to their radial configurations with the main source in-feed. In this regard, the protection system in such systems includes fuses, auto re-closers, and overcurrent relays [11, 29]. In the presence of DG, conventional distribution systems would no longer be radially configured, causing many challenges to protection systems which may ultimately lead to losing protection system coordination. In addition, some relays may be blinded [9, 29]. The challenges of the protection systems in the presence of DG would be as listed below [9, 29]:

- Unsynchronized reclosing

- Avoiding automatic reclosing

- Undesired islanding

- Contribution to the short-circuit level

- Protection system blinding

- Nuisance tripping of generating units

- Maloperation of feeder protection

It is implied that the problems associated with distribution system protection are highly dependent upon the characteristics of the distribution system and the type of DG utilized. Hence, the protection scheme must change according to the new configuration of the system. Traditional distribution systems are generally radial and supplied at one end in which designing protection schemes would be simple. Meanwhile, everincreasing penetration of DG in distribution systems may adversely affect the voltage and frequency control as well as protection systems. The presence of DG units turns the traditional distribution systems with radial configuration into grid networks since DG are active assets [30].

It should also be noted that the system reliability may deteriorate due to the undesired impact of DG on the protection system [11]. Overcurrent relays are the most commonly used as primary protection in distribution systems and in some cases as backup protection in transmission and sub-transmission networks. In presence of DG, the short-circuit levels would change and some challenging issues would arise. Therefore, adaptive relay coordination is necessary for distribution system protection [31].

It is worth noting that the contribution of a single DG unit may not significantly affect the fault current. However, in the case of several DG units connected to the system, the fault current and accordingly the protection system will be highly affected [32]. One possible solution to tackle this shortcoming is separating electrical distribution systems into smaller zones, or sub-areas [33]. By adding DG to the distribution 
system, sometimes it is necessary that the system operates in an islanded mode to enhance the reliability of supplying the customers' load demand [33].

Such conditions cause two different fault levels such that the short-circuit current seen by the relay when in the grid-connected mode is higher compared to the islanded mode. The combination of active distribution networks with DG and islanding operation causes situations in the system that affect the fault level and the direction of the fault current which eventually impacts the performance of overcurrent relays. In this respect, proposing effective and efficient solutions to improve the performance of the protection system seems vital; otherwise, the pros of DG will be outweighed by the cons.

Moreover, losing protection coordination with DG mainly results in the false tripping command and blinding of the protection system. The protection system becomes blind when the sensitivity of relays decreases, and the false tripping command occurs when the protective device sends a tripping command for a fault on a feeder while the fault has occurred on another feeder [6].

Much research has been carried out regarding the improvement of protection systems in the presence of DG. For instance, Coffele et al. [34] proposed a framework for protective relay settings with DG, active system management, and islanded operation. Since the number of probable states is too high under such conditions, pre-setting of protective relays would be practically impossible. Thus, the optimal protection setting was calculated and directly given to the protective relays. This change may be dependent on DG connection, the mode of grid connection, the islanding operation, and even the active system management. In case of DG units connected to the grid, the load flow between the grid and the consumer is bidirectional.

Hence, the direction of the fault current changes because of existing DG, which impacts the performance of the protection system. Therefore, Directional Overcurrent Relays (DOCRs) are used in modern distribution systems equipped with DG units. One key point to be taken into account is to appropriately predict the capacity of DG connected to the distribution system. In this respect, Huchel et al. [35] present a linear programming framework for calculating the settings of directional overcurrent relays in which all possible states for installed DG capacity have been considered.

In addition, there are several other approaches to mitigate the negative impacts of DG on the protection system in distribution networks, listed as follows:

- Tripping the DG immediately after detecting the fault.

- Restricting DG capacity.

- Utilizing adaptive protection [36-42].

- Changing or modifying the protection system by adding supplementary circuit breakers and reclosers, reconfiguration of the distribution system, employing directional overcurrent relays [4345], and distance relays [46, 47].

- Installing Fault Current Limiter (FCL) [48-50]. 
Kumar et al. [39] used a novel, fast, and adaptive protection scheme to protect distribution systems with DG. The suggested framework uses the Fast Recursive Discrete Fourier Transform (FRDFT) to track varying signals of the power system. Furthermore, the Fuzzy Logic Decision Making (FLDM) technique is employed to obtain optimal protection settings in case of changes in system conditions. Liu et al. [40] present an adaptive protection and control scheme in presence of DG which is based on the multi-agent control system to organize distributed relays and converter controllers operating together. It is noted that when there are DG units in meshed systems, the operating time of directional overcurrent relays would be of high importance.

Brahma et al. [41] proposed a system-independent adaptive protection system to protect distribution systems equipped with DG. Shen et al. [42] previously used a definite-time overcurrent protection which is multi-level for ungrounded distribution systems application with DG. The latter scheme solely utilizes local information of each bus, rather than relying on additional communication systems or Global Positioning System (GPS) synchronization. Zeineldin et al. [43] introduced an index named "Protection Coordination Index (PCI)" for coordinating DOCRs affected by synchronous DG units. This index is effective for planning the protection of meshed distribution systems. The suggested model has been formulated using the Two-Phase Non-Linear Programming (TPNLP) technique to optimally evaluate the impact of variation of DG maximum installed capacity on the variation of protection coordination time interval and determine the PCI.

In a later study, Zeineldin et al. [44] utilized dual-setting DOCRs to protect meshed distribution systems in presence of DG. It should be noted that these relays are equipped with two inverse time-current characteristics, whose settings depend on fault direction. In this regard, the protection coordination problem has been formulated within a Non-Linear Programming (NLP) framework in which the objective function is to minimize the total operating time of relays for both primary and backup protection. The relays have two settings for each possible fault current direction with two time dial and pick-up current settings.

Meanwhile, Aghdam et al. [51] showed that the results reported by Zeineldin et al. [43] were not valid and that dual-setting DOCRs do not bring significant advantages to the protection of distribution networks. Nikolaidis et al. [45] employed communication-based DOCRs to protect a radial distribution system. The protection scheme uses conventional DOCRs with intertripping and blocking transfer functions.

Additionally, Saleh et al. [52] assigned a novel time-voltage-current characteristic to DOCRs with the capability of remarkably reducing the operating time of relays. This method uses both voltage and current magnitudes to obtain the operating time of the relay using an NLP framework. The merit of this scheme would be its applicability to both synchronous and inverter-based DGs. Distance relays can be used in addition to overcurrent relays for protecting distribution systems with DG. This type of relay is directional and less affected by the variations of system conditions. 
In this respect, Sinclair et al. [46] utilized distance relays where feeders with DGs are considered with protection devices. Chilvers et al. [47] previously used distance protection for 11-kV distribution systems in the UK. The presented protection scheme provides the system with both primary and backup protection. Moreover, FCL has been used by El-Khattam et al. [48] to solve the protection coordination problem of DOCRs in the presence DG. As shown in Fig. 1, FCL is installed in series with DG so that during faults locally limits the DG's drawn current at the connected bus to the looped Power Delivery System (PDS). Consequently, the existing protective devices and schemes remain unchanged.

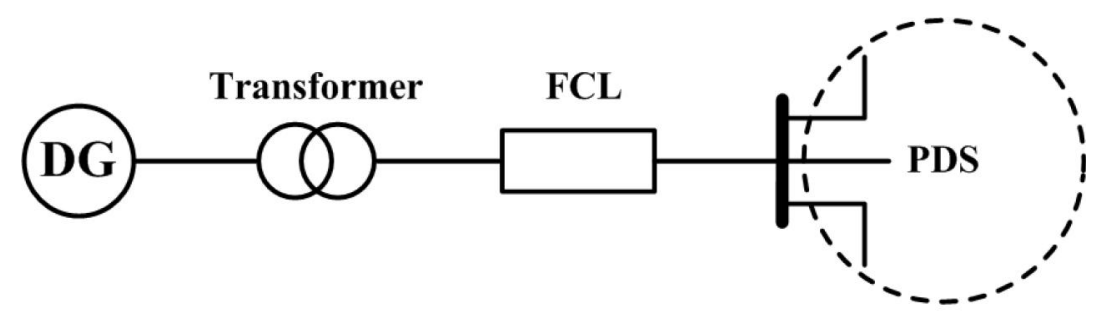

Fig. 1. FCL connection scheme in the presence of DG

Zhang et al. [50] suggested a dual-FCL scheme to restrict the DG's contribution to the fault current, which is concluded that it successfully managed to do so. Also, the frequency fluctuations of the DG would be limited, and consequently, the synchronization between new DG units and the electrical grid is enhanced.

Salem et al. [53] reduced the impact of DG on the mal-operation of overcurrent relays by controlling the inverter of inverter-based DG. Having used this approach, the injected power to the grid during the faults would be limited to the rated current of DG units. As a result, the injected current to the grid will be limited to the desired value by effectively controlling the reference power.

Meanwhile, Yazdanpanahi et al. [54] used a solid-state based field discharge circuit to decrease the contribution of DG to the fault current which enhances the compatibility of DG with distribution systems. With respect to the fact that DG units connect to electrical grids in parallel, it can be ccncluded that shortcircuit current increases by reducing the fault impedance. This claim can be proved using the equations derived from Fig. 2 [18].

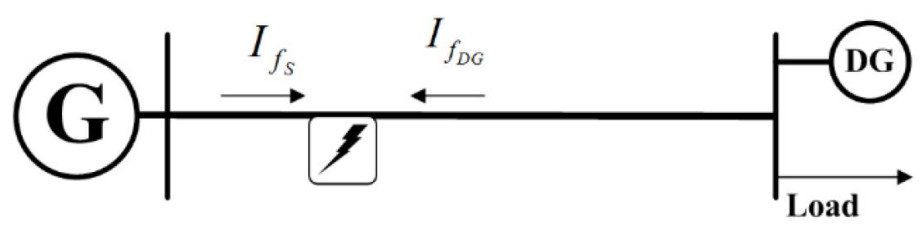

Fig. 2. The impact of DGs on the short-circuit current 
The short-circuit current component without DG can be stated as $\left|I_{f s}\right|$, while the total short-circuit current would be the sum of $\left|I_{f s}\right|$ and the component representing the fault current of the DG $\left|I_{D G}\right|$.

The fault current increases with DG, forcing the system operator to replace existing circuit breakers with new ones compatible with the new conditions. This key point must be taken into account: that optimal siting and sizing of DG may avoid any extra costs. Protection schemes of distribution systems can be categorized into traditional protection schemes with and without DG.

\subsection{Traditional protection schemes without DG}

This scheme includes the main power source, the connected loads, as well as the protective relays. An illustrative example is depicted in Fig. 3 to better elaborate this case.

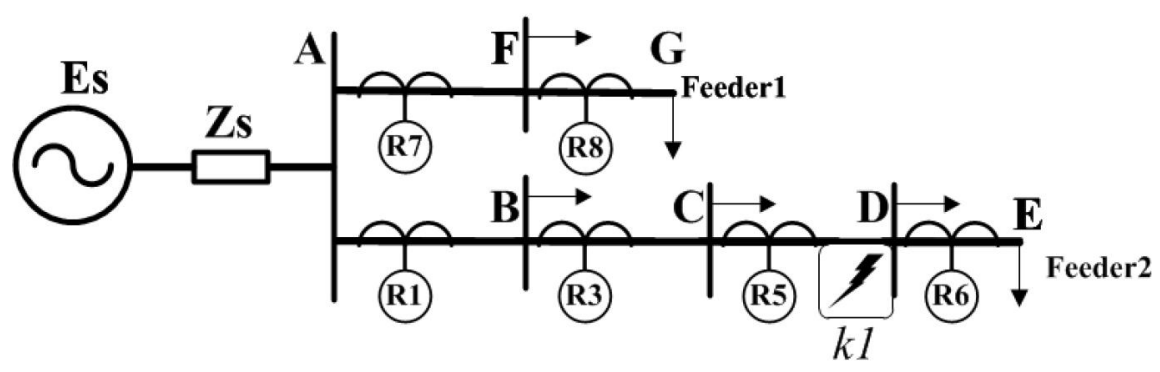

Fig. 3. A simple protection scheme without DG

As Fig. 3 indicates, protective relays are located next to buses at the side of the main power source, so the downstream parts of feeders are in the zones of relays. If a fault occurs at point $k_{l}$, relays $R_{5}, R_{3}$, and $R_{l}$ sense the short-circuit currents. In this situation, relays $R_{3}$ and $R_{5}$ operate as primary and backup protection, respectively. In other words, these relays start picking up. However, the tripping time of $R_{5}$ is less than $R_{3}$, and the tripping time of $R_{3}$ is less than $R_{l}$.

\subsection{The protection scheme in presence of $D G$}

DG integration within the previous scheme results in a more complete one. For DG installed at one given bus, e.g., bus $C$, the previous example changes as depicted in Fig. 4. 


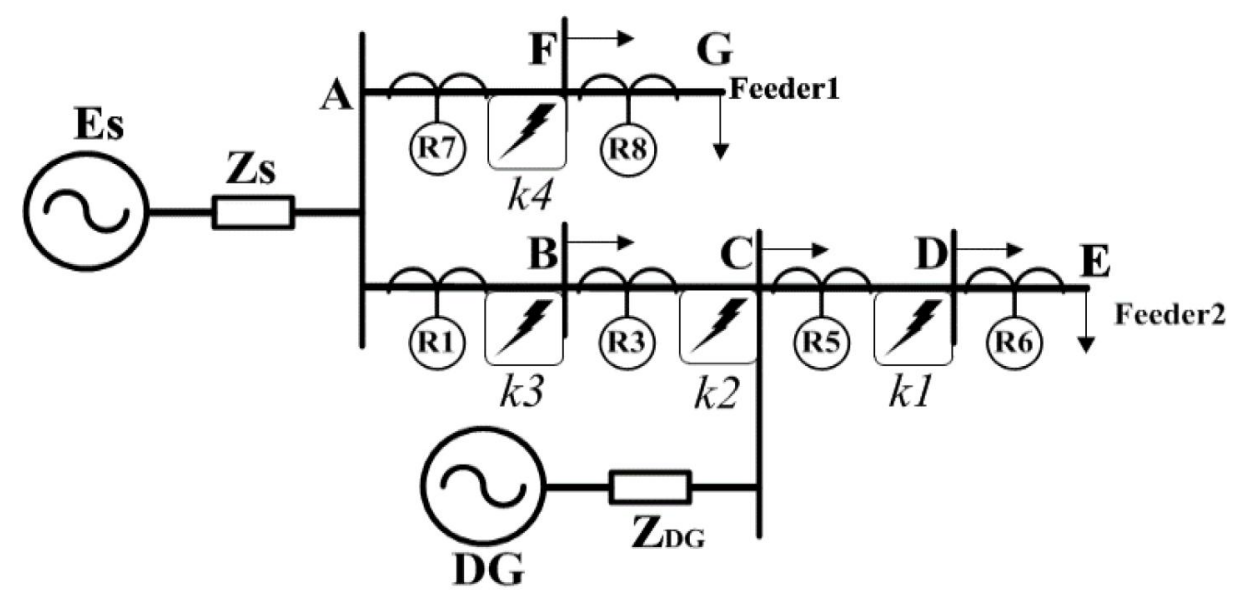

Fig. 4. Protection scheme of a sample system with a DG

If a fault occurs at point $k_{l}$, the measured fault current at the main relay $R_{5}$ would increase, leading to false operation of this relay. At this time, the protected zones of $R_{1}$ and $R_{3}$ as backup relays decrease. Indeed, it can be stated that the sensitivity of relays $R_{1}$ and $R_{3}$ decreases causing them not to operate properly.

If a fault occurs at point $k_{2}$, relays $R_{1}$ and $R_{3}$ would sense the fault and react to the fault current injected by the main power source $\left(E_{s}\right)$. Besides, after operation of $R_{1}$ and $R_{3}$, a fault current is injected to the fault location by the DG, causing an electric arc which finally defers feeder reclosing.

If a fault occurs at point $k_{3}$, relay $R_{l}$ can properly send the right tripping command for fault current due to the main power source. Simultaneously, the fault current injected by the DG causes malfunction of relay $R_{3}$.

For the faults occurring at point $k_{4}$, the current seen through relay $R_{7}$ increases because the DG endangers the protection selectivity. In this regard, if relays $R_{I}$ and $R_{3}$ are not directional, it may lead to malfunction and the spreading of the fault throughout the system [55].

So far, improvement of protection schemes has attracted the attention of many researchers. For instance, a new islanding detection method with DG has been proposed by Marchesan et al. [56], which requires a small computational burden making it suitable for protective relays. Moreover, according to the solution presented in an earlier study by Javadian et al. [29], the distribution system with DG can be separated into different zones. Each zone has the capability of islanded operation, where risk assessment has been carried out to optimize the protection zones by optimal siting of protective devices. Risk assessment of the protection system was similarly performed by.Javadian et al. [9], who take into account different sites and sizes of DG units. Table 1 presents the taxonomy of the reviewed papers regarding the impact of DG on the protection of distribution systems. 
Table 1. Taxonomy of reviewed papers on the impacts of DG on protection systems.

\begin{tabular}{|c|c|c|c|}
\hline Ref & Problem & Method & Protection challenges \\
\hline [29] & $\begin{array}{c}\text { Adaptive centralized protection } \\
\text { scheme for distribution systems with } \\
\text { DG }\end{array}$ & $\begin{array}{c}\text { Dividing an existing distribution } \\
\text { network into several zones, each capable } \\
\text { of operating in island mode. }\end{array}$ & $\begin{array}{l}\text { Determining the fault location and type in the } \\
\text { presence of DGs }\end{array}$ \\
\hline [31] & $\begin{array}{l}\text { Overcurrent protection of distribution } \\
\text { systems with DGs }\end{array}$ & $\begin{array}{l}\text { Boundary wavelet coefficient energy to } \\
\text { detect the fault inception time }\end{array}$ & $\begin{array}{l}\text { Reducing the relay operating time in presence } \\
\text { of DGs }\end{array}$ \\
\hline [34] & $\begin{array}{l}\text { Distribution system adaptive } \\
\text { overcurrent protection }\end{array}$ & $\begin{array}{l}\text { Directly applying the } \\
\text { optimum protection settings to the relays }\end{array}$ & $\begin{array}{l}\text { Decreasing the false operations and reducing } \\
\text { the mean operating time with DGs }\end{array}$ \\
\hline [35] & Planning the coordination of DOCRs & Simplex method & $\begin{array}{l}\text { Obtaining an individual set of settings suitable } \\
\text { for all DG installation scenarios }\end{array}$ \\
\hline [36] & $\begin{array}{l}\text { Optimal coordination of overcurrent } \\
\text { relays }\end{array}$ & Multi-agent coordination approach & $\begin{array}{l}\text { The communication system to provide the } \\
\text { required information for Protection } \\
\text { coordination }\end{array}$ \\
\hline [38] & $\begin{array}{l}\text { Distribution system overcurrent } \\
\text { protection }\end{array}$ & Adaptive overcurrent relaying & $\begin{array}{c}\text { The reduced reach of overcurrent relays in } \\
\text { presence of inverter-based DGs }\end{array}$ \\
\hline [39] & $\begin{array}{l}\text { Distribution system protection with } \\
\text { DGs }\end{array}$ & $\begin{array}{l}\text { Adaptive overcurrent relaying using a } \\
\text { fuzzy-logic decision-making module }\end{array}$ & $\begin{array}{c}\text { Capturing different system operation and } \\
\text { topology scenarios }\end{array}$ \\
\hline [41] & $\begin{array}{l}\text { Optimal coordination of overcurrent } \\
\text { relays }\end{array}$ & Adaptive overcurrent relaying & $\begin{array}{l}\text { Obtaining the optimal setting with the high } \\
\text { penetration of DGs }\end{array}$ \\
\hline [42] & $\begin{array}{l}\text { Adaptive multi-stage definite-time } \\
\text { overcurrent } \\
\text { protection scheme for ungrounded } \\
\text { distribution systems with DGs }\end{array}$ & $\begin{array}{l}\text { The optimized Thevenin equivalent } \\
\text { parameters estimation using local } \\
\text { available measurements. }\end{array}$ & $\begin{array}{l}\text { The online calculation of fault current for } \\
\text { different systems conditions }\end{array}$ \\
\hline [43] & $\begin{array}{l}\text { Optimal protection coordination of } \\
\text { DOCRs for looped distribution } \\
\text { systems equipped with DGs. }\end{array}$ & $\begin{array}{l}\text { Proposing a protection coordination } \\
\text { index and determining the index using } \\
\text { NLP method. }\end{array}$ & $\begin{array}{l}\text { Calculating the PCI by optimally determining } \\
\text { DG penetration level variations with respect to } \\
\text { the coordination time interval changes. }\end{array}$ \\
\hline [44] & $\begin{array}{l}\text { Optimal protection coordination of } \\
\text { the } \\
\text { dual setting directional relays for } \\
\text { distribution networks with DGs. }\end{array}$ & Dual setting DOCRs & $\begin{array}{l}\text { Keeping the DG in service during fault } \\
\text { conditions by avoiding unintentional DG } \\
\text { disconnection. }\end{array}$ \\
\hline [46] & $\begin{array}{l}\text { Protection of active distribution } \\
\text { systems }\end{array}$ & Using distance relays & $\begin{array}{l}\text { loss of protection sensitivity, loss of protection } \\
\text { coordination, and tripping for out-of- } \\
\text { zone faults in the presence of DGs. }\end{array}$ \\
\hline [48] & $\begin{array}{l}\text { DOCR coordination with DGs for } \\
\text { looped distribution systems }\end{array}$ & Using FCL & $\begin{array}{c}\text { Keeping the original settings of relays } \\
\text { unchanged }\end{array}$ \\
\hline$[\mathbf{5 0}]$ & $\begin{array}{l}\text { Protection of distribution system for } \\
\text { DG connection to the grid }\end{array}$ & Dual-FCL connection & $\begin{array}{l}\text { Keeping the original protection relay settings, } \\
\text { and enhancing the synchronism between the } \\
\text { DG and the grid. }\end{array}$ \\
\hline [52] & $\begin{array}{l}\text { Optimal protection coordination of } \\
\text { DOCRs in meshed distribution } \\
\text { networks with DGs. }\end{array}$ & $\begin{array}{l}\text { Using a nonstandard relay characteristic } \\
\text { dependent on current and voltage } \\
\text { magnitudes }\end{array}$ & $\begin{array}{l}\text { Reducing the relay operating tie in presence of } \\
\text { DGs }\end{array}$ \\
\hline [53] & $\begin{array}{l}\text { Integrating inverter-based DGs into } \\
\text { distribution networks. }\end{array}$ & $\begin{array}{l}\text { Proposing a modified inverter control to } \\
\text { limit the fault current contribution of the } \\
\text { DG }\end{array}$ & $\begin{array}{l}\text { Reducing the } \\
\text { mal-operation of the over current protection } \\
\text { coordination with DGs }\end{array}$ \\
\hline [54] & $\begin{array}{l}\text { Reducing the impact of synchronous- } \\
\text { machine DGs on the distribution } \\
\text { system protection coordination }\end{array}$ & $\begin{array}{l}\text { Proposing a solid-state switch-based } \\
\text { field discharge circuit for the DG }\end{array}$ & $\begin{array}{l}\text { Reducing the contribution of the synchronous- } \\
\text { machine DGs to the fault current }\end{array}$ \\
\hline [55] & $\begin{array}{c}\text { Protection of distribution systems } \\
\text { with DGs }\end{array}$ & $\begin{array}{l}\text { Adaptive voltage protection based on } \\
\text { Intelligent Electronic Devices (IEDs) for } \\
\text { distribution network with DGs }\end{array}$ & $\begin{array}{l}\text { Dealing with the impact of DGs on the over- } \\
\text { current protection }\end{array}$ \\
\hline [57] & $\begin{array}{c}\text { Optimal coordination of overcurrent } \\
\text { relays }\end{array}$ & $\begin{array}{l}\text { Implementing the user-defined settings } \\
\text { for DOCRs }\end{array}$ & Accelerating the clearing time for DOCRs \\
\hline$[58]$ & $\begin{array}{c}\text { Optimal coordination of DOCRs in } \\
\text { active radial and meshed distribution } \\
\text { networks }\end{array}$ & $\begin{array}{l}\text { A two-stage method using hybrid linear } \\
\text { programming and cuckoo search }\end{array}$ & $\begin{array}{l}\text { Uncertainties due to changes in operation } \\
\text { conditions, changes in fault conditions, error in } \\
\text { measuring equipment, and outage of DGs }\end{array}$ \\
\hline
\end{tabular}




\section{Voltage regulation in the presence of DG}

As previously mentioned, adding DG into existing power networks may cause different problems due to the fact that conventional electrical grids were designed to supply load demand from the generation side. Unidirectional power flow has been foreseen for such networks. In case of connecting DG to the system, the power flow would be bidirectional as the extra power produced by DG is fed back to the generation side.

Bidirectional power flow significantly impacts the distribution system with regards to voltage regulation and system protection, as well as the operation. The previous section investigated the protection issue raised by DG integration. This section seeks to provide a comprehensive review on the solutions to voltage regulation issues, as this topic is considered one of the vital issues for distribution systems.

Voltage regulation may adversely restrict DG penetration into the electrical grids. Having bidirectional power flow, the voltage regulation of the system would require modern techniques [59-62]. Indeed, some factors can affect DG integration into electrical grids as follows [63, 64]:

- The voltage level at which DG is connected.

- The type of the distribution system.

- The value of the load demand.

- The size of DG.

The voltage profile, the power losses and the short-circuit level are affected by above factors. In this regard, two key points should be noted due to the higher value of $\frac{R}{X}$; First, the voltage drop in distribution systems is higher compared to transmission systems and second, the DG's active power output has a more significant impact on the voltage profile than that of reactive power [63].

Accordingly, two types of methods have been proposed to regulate voltage in distribution systems with DG. These methods can be categorized into traditional and modern techniques. One of the most influential and effective solutions to maximize the DG penetration into electrical grids is active network management. Using this strategy, the system operator would be able to make the most of the current network by establishing some management policies [65]. This program would provide distribution systems with different capabilities such as real-time monitoring, communication, and network control using different assets. Intelligent distributed control is another solution that has been proposed to regulate the distribution network voltage at desired values [66]. In 2014, Muttaqi et al. [67] published a review of the control issues of distribution systems with DG. Moreover, Antoniadou-Plytaria et al. [68] recently carried out a comprehensive review on distributed and decentralized control methods for controlling the voltage of distribution networks. As the location of the DG highly impacts the voltage profile, the system topology 
must be taken into account when planning a control strategy. It should be noted that different sites for DG would result in different effects.

In this respect, conventional solutions proposed for voltage control are usually based on three different assets: On-Load Tap Changer (OLTC), switched capacitors, and step voltage regulators known as Static Voltage Regulators (SVR).

The aim behind using the OLTC is regulating the voltage level of a transformer by changing the number of turns in secondary winding, which changes the transformer turn ratio. This is done automatically in a way that the feeder current at the substation end is measured and voltage drop through the distribution feeder is predicted to set the tap. The conditions along the feeder can be neither estimated nor controlled by the OLTC in presence of DG [69].

It should be noted that using OLTC may cause detrimental impacts on voltage stability such that voltage collapse may be plausible [70]. Studies show that while OLTC attempt to restore the load bus voltage to the level before the disturbance occurs, it may facilitate the voltage collapse procedure [70]. However, neither OLTC nor switched capacitors are able to react quickly to the changes [71, 72].

Besides, there are some modern techniques developed to cope with the voltage variation problem in distribution networks using controllable components, and are listed as follows:

- Supply-side power curtailment.

- Distribution system reconfiguration.

- Area-based OLTC coordinated voltage control.

- Employing Static Synchronous Compensator (STATCOM).

- Employing inverter-based DGs.

- Demand-Side Management (DSM) strategies.

- Installing electrical Energy Storage Systems (ESSs).

- Supply-side power curtailment

In some cases, due to the lack of flexible voltage regulation methods, the distribution network operator may disconnect all DG from the grid to deal with voltage rise issues. This action would deprive the entire system of the benefits of such units, particularly RES-based ones [73]. In this respect, power curtailment of the DG units would be an effective solution to deal with variations of system voltage by optimally decreasing the power output of DG units. However, the agreements between the system operator and DG owners in case of private DG ownership would be the key point. This method can be simply implemented for dispatchable DG units, while pitch angle control can be employed to control the speed of the wind turbine to implement the power curtailment for wind turbines due to their intermittent nature. 
Chalise et al. [74] utilized active power curtailment of wind turbines to tackle the overvoltage problem in distribution systems caused by DG integration. In case of high penetration of PV in the electrical grid, voltage rise may happen at the point of connection which in turn restricts potential PV integration into the grid. Therefore, the active and reactive power can be altered to reduce this voltage rise [75].

On the other hand, Zeraati et al. [76] suggested PEV batteries together with active power curtailment of PV arrays to deal with the voltage rise problem in Low Voltage (LV) distribution systems. The reactive power capability along with the active power curtailment of PV has been integrated into a multi-objective framework previously proposed by Su et al. [77] to address the voltage variation issue in unbalanced fourwire LV distribution networks.

\section{- Distribution system reconfiguration}

Distribution system reconfiguration can be defined as the procedure of closing or opening the switches between two radial feeders such that meshed operation can be achieved. Through this technique, several advantages can be obtained including losses reduction, voltage profile improvement, and full exploitation of available system resources.

Liu et al. [78] presented a reconfiguration framework for unbalanced distribution systems aimed at minimizing the total operation cost with optimal operations of voltage regulation devices, including Voltage Regulators (VRs), Static VAR Compensators (SVCs), Distributed STATCOMs (D-STATCOMs), Distributed Energy Resources (DERs), and shunt capacitor banks. A combination of reactive power optimization and network reconfiguration has been presented by Tian et al.[79] to minimize the power losses while omitting the voltage deviations in presence of DG. In 2017, Badran et al. [80] reviewed the methods used for the distribution system reconfiguration integrated with DG.

\section{- OLTC}

Utilizing the capabilities of the OLTC is one of the most common solutions for voltage regulation problems in distribution networks. This is done by optimally choosing the best phase angle shift and adjusting the voltage magnitude. However, as mentioned above, OLTC should be used while coordinated with other voltage regulation devices to effectively and efficiently impact the voltage regulation issues in power systems. Thus far, many research works have investigated the application of OLTC to regulate voltage.

With the aim of maximizing PV penetration, Hu et al. [81] employed coordinated voltage control of a decoupled three-phase OLTC along with the PV unit reactive power supply to cope with the voltage rise problem in distribution systems. Moreover, OLTC has been used by Kabiri et al. [82] to regulate voltage in presence of PV units, where DG also has the capability to regulate voltage. In this regard, Muttaqi et al. [83] 
proposed a coordinated control strategy for regulating voltage by means of DG together with OLTC and voltage regulators.

According to the coordinated voltage control strategy used in the latter study [83], DG would function as VRs while currently the negative interactions between the OLTC of distribution transformers as well as active devices with DG can be eliminated or even reduced. Parallel operation of OLTC control and PV reactive power provision of PV units were addressed in a study by Kraiczy et al. [84], mainly emphasizing unwanted interactions between these two devices. A coordinated control framework has been presented by Salih et al. [85] to regulate voltage in distribution systems. To this end, the reactive power provision of wind turbines and the OLTC have been utilized in a coordinated way.

The coordinated operation of SVC and the OLTC in the presence of PV units to regulate voltage has been investigated by Daratha et al. [86]. A coordinated voltage regulation algorithm has been developed by Mehmood et al. [87] using capacitor banks and OLTC together with the capabilities of PV, wind turbines, and other dispatchable DG. Moreover, DG, ESS, and OLTC can be used within a coordinated framework to regulate voltage in active distribution systems [88]. The power curtailment strategy together with the OLTC has been used in a study by Azzouz et al. [89] utilizing a three-level fuzzy-based control technique. A comprehensive review on different methods for voltage control using the OLTC has been carried out in 2013 by Sarimuthu et al. [90].

\section{- $\quad$ STATCOM}

Static synchronous compensator known as STATCOM is categorized into Flexible AC Transmission Systems (FACTS) devices based on Voltage Source Convertor (VSC), with the capability of providing the system with reactive power compensation. By controlling the reactive power of the STATCOM, the voltage at the point of connection can be regulated in either transmission or distribution systems.

Due to STATCOM advantages such as its fast response, it has been widely used in power systems for different purposes. It can be employed in distribution systems to provide the voltage regulation service to the network.

Coordinated operation of D-STATCOM, OLTC and SVC has been investigated by Lee et al. [91], in the presence of DG for voltage regulation (both the positive and the negative sequence voltages). The coordinated operation framework of OLTC and D-STATCOM has been presented in a study by Zad et al. [92] to tackle the voltage regulation problem in Medium Voltage (MV) systems integrated with DG. A comprehensive review on different methods for reactive power compensation has been carried out in by Gayatri et al. [93].

- Employing inverter-based DG units 
The capabilities of inverter-based DG units have turned them into active assets in regulating voltage by optimally controlling the reactive power injection/absorption to/from the grid. For instance, PV-based DG units are not only able to inject power to the grid, but also inject/absorb reactive power to/from the electrical grid to enhance voltage regulation of the system [94].

Also, an intelligent control method based on fuzzy and classical Proportional-Integral (PI) controller has been proposed in by Anantwar et al. [95] for reactive power control of PV in a microgrid equipped with synchronous-machine diesel and induction-machine based wind turbine. Samadi et al. [96] presented a coordinated characteristic curve, $\mathrm{Q}(\mathrm{P})$, for each PV system along a feeder to regulate the voltage so that the voltage values remain below the steady-state voltage bound.

The capability of PV inverters to enhance voltage variations by efficiently controlling the active and reactive power output, in Australia, has been investigated in by Collins et al. [97]. The possibility of regulating voltage in distribution systems using the PV solar farms has been assessed in a study by Varma et al. [98]. PV solar farms would be able to regulate the voltage at the Point of Common Coupling (PCC) in the presence of uncertain wind power generation and load demand during the nighttime.

\section{- Demand-side management strategies}

Demand side management programs can be defined as agreements between the system operator and the consumers to optimally put into effect required actions to enhance the efficiency of the system, which in turn enhances the benefits of all aspects including the consumer, the system operator, and eventually the society. In general, using DSM strategies, the rise in total power demand leads to decreasing system security and stability. DSM strategies are usually implemented in LV distribution systems. Employing DSM programs, the load would be controlled and modulated in case of necessity by the system operator through an agreement with the consumers to modify their consumption accordingly.

A real-time framework has been suggested Zakariazadeh et al. [99] for voltage control on the basis of demand response programs. This framework uses data collected by Remote Terminal Units (RTUs), specifying the optimal tap changer conditions as well as the amount of load to be curtailed in case it is needed. The applicability of an ice-thermal storage with an electric spring as a smart load has been discussed by Luo et al. [100] to provide voltage control and DSM with fast response in buildings.

A study by Chen et al. [101] employed the electric spring concept in a dynamic load response framework for voltage and frequency control in the presence of intermittent wind power. Furthermore, the performance of an electric spring and STATCOM have been compared by Luo et al. [102] in the context of voltage control and demand response programs, where it has been shown that the electric spring provides the distribution system with more favorable total voltage regulation. An autonomous load scheduling method has been suggested by Yao et al. [103] considering the PV power output's uncertainty for both peak shaving 
and mitigating the reverse power flow due to PV units which causes voltage rise. Malik et al. [104] developed a two-stage DSM framework for the distribution systems with large penetration of RES. In this respect, a centralized direct control has been presented for an electric water heater which can effectively mitigate voltage variations. Muttaqi et al. [105] proposed the applicability of DG to load management. A comprehensive review on the application of load shedding techniques in distribution systems with DG presence has been recently carried out by Sapari et al. [106].

\section{- Energy Storage Systems}

ESSs have been introduced to power systems as an energy source with almost zero emission, capable of providing the system and RESs with the required reserve. Such devices are connected to the electrical grid using a power conversion system and are able to tackle the voltage variation problem in distribution systems by injecting/absorbing active and reactive power to/from the electrical grid. It should be noted that such a capability can be achieved over short-term and mid-term horizons while for long-run voltage variation issues, a huge investment must be made.

The main concern with ESSs relates to their high cost. ESSs have been so far utilized in power systems due to their capability to provide reserve and regulate the voltage. A Vanadium Redox Battery (VRB) has been utilized by Wang et al. [107] to solve the voltage rise and drop issues due to deep penetration of rooftop PVs. Nazaripouya [108] proposed a planning framework for sizing battery ESSs to regulate the voltage variations in presence of PVs. A coordinated charging/discharging strategy has been suggested by Lee et al. [109] based on battery ESSs to reduce the voltage and frequency variations where the main control center is responsible for managing the ESS. Besides, the applicability of employing a coordinated strategy for managing multiple ESSs has been evaluated in a study by Wang et al. [110] to deal with the voltage rise due to increased PV penetration.

The optimal integration problem of battery ESSs has been investigated by Jayasekara et al. [111] for achieving different goals including voltage regulation, loss reduction and peak shaving, which finally leads to maximizing DG capabilities in distribution systems. Krishan et al. [112] discussed the voltage rise problem in distribution systems caused by high penetration of solar PV. In this regard, a coordinated controlled voltage regulation approach on the basis of dynamic droop with battery ESSs has been suggested to solve the problem of voltage rise and voltage drop in an active DC distribution network.

Table 2 presents taxonomy of some of reviewed references regarding the voltage regulation of distribution systems in the presence of DG. 
Table 2. Taxonomy of reviewed papers on voltage regulation of distribution systems in the presence of DG

\begin{tabular}{|c|c|c|}
\hline Ref & Problem & Solution \\
\hline [73] & Voltage regulation in distribution systems with DGs & Active and reactive power control of DG \\
\hline [74] & Overvoltage mitigation with small wind turbines & $\begin{array}{l}\text { Active power curtailment of small wind turbines by controlling } \\
\text { the pitch angle }\end{array}$ \\
\hline [75] & Voltage rise mitigation due to large $\mathrm{PV}$ penetration & $\begin{array}{c}\text { Droop-based inverter reactive power compensation and active } \\
\text { power curtailment of PVs }\end{array}$ \\
\hline [76] & $\begin{array}{l}\text { Voltage rise reduction due to rooftop PVs and Voltage drop } \\
\text { compensation due to peak load demand }\end{array}$ & $\begin{array}{l}\text { Active power curtailment of PV arrays and battery management } \\
\text { of PEVs }\end{array}$ \\
\hline [77] & $\begin{array}{l}\text { Improving the performance of severely unbalanced three- } \\
\text { phase four-wire low voltage distribution networks with high } \\
\text { residential PV penetrations }\end{array}$ & $\begin{array}{c}\text { Optimal reactive power control and real power curtailment of } \\
\text { single-phase inverters of PVs }\end{array}$ \\
\hline [78] & $\begin{array}{l}\text { Optimal network reconfiguration problem of unbalanced } \\
\text { distribution systems considering the voltage issues caused by } \\
\text { DERs. }\end{array}$ & $\begin{array}{l}\text { Optimal operations of voltage regulation devices, including VRs, } \\
\text { SVCs, D-STATCOMs, and shunt capacitor banks }\end{array}$ \\
\hline [79] & $\begin{array}{c}\text { Reducing voltage violations due to high DG penetration with } \\
\text { low load demand or low DG penetration with high load } \\
\text { demand. }\end{array}$ & Combination of VAR optimization and network reconfiguration. \\
\hline [81] & $\begin{array}{l}\text { Mitigating voltage rise due to PVs and uneven connection of } \\
\text { single-phase generation }\end{array}$ & $\begin{array}{l}\text { Using transformers with single-phase tapping capability and } \\
\text { reactive power control of PV systems }\end{array}$ \\
\hline [83] & $\begin{array}{l}\text { DG participation in voltage regulation in the presence of } \\
\text { OLTC and VR }\end{array}$ & Proposing a control coordination technique \\
\hline [85] & $\begin{array}{l}\text { Voltage regulation in distribution systems in presence of } \\
\qquad \text { DGs }\end{array}$ & $\begin{array}{l}\text { Coordinated framework for OLTC and reactive power control of } \\
\text { wind turbines }\end{array}$ \\
\hline$[86]$ & $\begin{array}{l}\text { Optimal voltage regulation in unbalanced radial distribution } \\
\text { system in presence of PV generation. }\end{array}$ & Coordinated control of OLTC and SVC \\
\hline [87] & Voltage rise mitigation due to large penetration of DGs & $\begin{array}{c}\text { Coordinated operation of OLTC, capacitor banks, PV, wind } \\
\text { power and dispatchable DGs }\end{array}$ \\
\hline$[88]$ & $\begin{array}{l}\text { Optimal voltage regulation of distribution systems with large } \\
\text { penetration }\end{array}$ & Coordinated control of PVs, ESSs and OLTCs \\
\hline [89] & Optimal voltage regulation of active distribution systems & $\begin{array}{l}\text { Applying fuzzy logic for coordinated control of OLTCs, } \\
\text { PVs and wind turbines }\end{array}$ \\
\hline [91] & $\begin{array}{c}\text { Voltage regulation of distribution systems equipped with } \\
\text { renewable DGs }\end{array}$ & Using D-STATCOM \\
\hline$[92]$ & $\begin{array}{l}\text { Voltage regulation of MV networks with radial } \\
\text { configuration }\end{array}$ & Coordinated control of OLTC and D-STATCOM \\
\hline [94] & Voltage regulation in presence of PVs & Controlling the inverter of PVs for reactive power injection \\
\hline [95] & $\begin{array}{l}\text { Voltage regulation of distribution systems with renewable } \\
\text { DGs and diesel engine }\end{array}$ & Controlling the reactive power of PV inverter \\
\hline$[96]$ & Reduction of voltage rise due to large penetration of PVs & $\begin{array}{l}\text { Coordinating the relation between reactive } \\
\text { power and corresponding feed-in power of each PV system in a } \\
\text { radial grid }\end{array}$ \\
\hline [97] & $\begin{array}{l}\text { Voltage rise mitigation in distribution systems in Australia } \\
\text { with large penetration of residential PVs }\end{array}$ & $\begin{array}{l}\text { Real and reactive power control of distributed PV inverter } \\
\text { systems }\end{array}$ \\
\hline [99] & $\begin{array}{c}\text { Real-time voltage regulation in the presence of variable DG } \\
\text { power generation }\end{array}$ & $\begin{array}{l}\text { Emergency demand response program by determining the tap } \\
\text { changer condition and load curtailment }\end{array}$ \\
\hline$[100]$ & $\begin{array}{l}\text { Voltage control and DSM in electrical grids equipped with } \\
\text { fluctuating wind power }\end{array}$ & Large-scale ice-thermal storage \\
\hline [101] & $\begin{array}{l}\text { Controlling voltage and frequency fluctuations due to } \\
\text { intermittent wind power }\end{array}$ & Demand response programs using an electric spring \\
\hline [102] & Voltage regulation of distribution systems & Distributed control of electric springs \\
\hline [103] & $\begin{array}{c}\text { Mitigating the voltage rise due to large penetration of } \\
\text { residential rooftop PVs }\end{array}$ & $\begin{array}{l}\text { DSM using an autonomous energy consumption scheduling } \\
\text { method }\end{array}$ \\
\hline [107] & $\begin{array}{c}\text { Mitigating the voltage rise due to large penetration of } \\
\text { residential rooftop PVs }\end{array}$ & Employing VRB ESSs \\
\hline [109] & $\begin{array}{l}\text { Voltage and frequency deviations reduction in distribution } \\
\text { systems. }\end{array}$ & Distributed Li-ion battery ESSs \\
\hline [110] & Mitigation of over-voltages due to large penetration of PVs & Coordinated operation of multiple lead-acid battery ESSs \\
\hline
\end{tabular}




\section{Conclusion}

Distributed Generation (DG) has been introduced to power systems, particularly at the Low Voltage (LV) level, to make the existing systems more reliable, secure, and efficient. Simultaneously, DG bring different challenges to the system as existing systems are not yet ready to accommodate high DG penetration levels. In this respect, the two main problems are related to protection systems and voltage regulation issues. Since the current and future trend of electric power systems is set towards increased integration of DG, particularly Renewable Energy Sources (RES)-based units, a discussion of the impacts of those generation technologies on distribution networks in needed. In the presence of DG, the protection system setting is exposed to challenges due to changes in the magnitude and direction of the fault currents. DG units contribute to the fault current and mainly affect the overcurrent protection systems with regards to protection coordination. In this regard, alternative protection systems and algorithms can be used such as Directional Overcurrent Relays (DOCRs). Besides, high-penetration DG, such as photovoltaic (PV) units, may cause overvoltage in distribution systems which should be effectively treated. Thus, this paper reviewed the problems caused by the DG regarding protection systems and voltage regulation of distribution networks. Accordingly, the solutions proposed to mitigate the adverse impact of DG have been investigated in detail. Overall, a comprehensive review has been made on the impact of DG on distribution systems both from the protection and voltage regulation points of view.

\section{References}

[1] Muthukumar K, Jayalalitha S. Optimal placement and sizing of distributed generators and shunt capacitors for power loss minimization in radial distribution networks using hybrid heuristic search optimization technique. International Journal of Electrical Power \& Energy Systems. 2016;78:299-319.

[2] Petinrin JO, Shaaban M. Impact of renewable generation on voltage control in distribution systems. Renewable and Sustainable Energy Reviews. 2016;65:770-83.

[3] Esmaili M, Firozjaee EC, Shayanfar HA. Optimal placement of distributed generations considering voltage stability and power losses with observing voltage-related constraints. Applied energy. 2014; 113:1252-60.

[4] Roy N, Pota HR. Current status and issues of concern for the integration of distributed generation into electricity networks. IEEE Systems journal. 2015;9:933-44.

[5] Delfanti M, Falabretti D, Merlo M. Dispersed generation impact on distribution network losses. Electric Power Systems Research. 2013;97:10-8. 
[6] Firouz Y, Farhadkhani S, Lobry J, Vallée F, Khakpour A, Durieux O. Numerical comparison of the effects of different types of distributed generation units on overcurrent protection systems in MV distribution grids. Renewable Energy. 2014;69:271-83.

[7] Xyngi I, Popov M. An intelligent algorithm for the protection of smart power systems. IEEE Transactions on smart grid. 2013;4:1541-8.

[8] Archana S, Rajpurohit BS, Lingfeng W. DG Integration with Power Quality Improvement Feature for Smart Grid. In: Pant M, Deep K, Bansal JC, Nagar A, Das KN, editors. Proceedings of Fifth International Conference on Soft Computing for Problem Solving. Singapore: Springer Singapore; 2016. p. 901-13.

[9] Javadian S, Haghifam M-R, Firoozabad MF, Bathaee S. Analysis of protection system's risk in distribution networks with DG. International Journal of Electrical Power \& Energy Systems. 2013;44:68895.

[10] Prakash P, Khatod DK. Optimal sizing and siting techniques for distributed generation in distribution systems: A review. Renewable and Sustainable Energy Reviews. 2016;57:111-30.

[11] Manditereza PT, Bansal R. Renewable distributed generation: The hidden challenges-A review from the protection perspective. Renewable and Sustainable Energy Reviews. 2016;58:1457-65.

[12] Karatepe E, Ugranlı F, Hiyama T. Comparison of single-and multiple-distributed generation concepts in terms of power loss, voltage profile, and line flows under uncertain scenarios. Renewable and Sustainable Energy Reviews. 2015;48:317-27.

[13] Rajaram R, Kumar KS, Rajasekar N. Power system reconfiguration in a radial distribution network for reducing losses and to improve voltage profile using modified plant growth simulation algorithm with Distributed Generation (DG). Energy Reports. 2015;1:116-22.

[14] Bagheri A, Monsef H, Lesani H. Integrated distribution network expansion planning incorporating distributed generation considering uncertainties, reliability, and operational conditions. International Journal of Electrical Power \& Energy Systems. 2015;73:56-70.

[15] Bayat A, Bagheri A, Noroozian R. Optimal siting and sizing of distributed generation accompanied by reconfiguration of distribution networks for maximum loss reduction by using a new UVDA-based heuristic method. International Journal of Electrical Power \& Energy Systems. 2016;77:360-71.

[16] Kayal P, Chanda C. Optimal mix of solar and wind distributed generations considering performance improvement of electrical distribution network. Renewable Energy. 2015;75:173-86.

[17] Zahedi A. A review of drivers, benefits, and challenges in integrating renewable energy sources into electricity grid. Renewable and Sustainable Energy Reviews. 2011;15:4775-9. 
[18] Hosseini S, Karami M, Madahi SK, Razavi F, Ghadimi A. Finding the optimal capacity and location of distributed generation resources and analyzing the impact of different coefficient factors. J Basic Appl Sci Res. 2011;1:2578-89.

[19] Hung DQ, Mithulananthan N, Bansal R. Analytical expressions for DG allocation in primary distribution networks. IEEE Transactions on energy conversion. 2010;25:814-20.

[20] Javadi MS, Anvari-Moghaddam A, Guerrero JM. Optimal scheduling of a multi-carrier energy hub supplemented by battery energy storage systems. 2017 IEEE International Conference on Environment and Electrical Engineering and 2017 IEEE Industrial and Commercial Power Systems Europe (EEEIC / I\&CPS Europe). 2017. p. 1-6.

[21] Bhide A, Monroy CR. Energy poverty: a special focus on energy poverty in India and renewable energy technologies. Renewable and Sustainable Energy Reviews. 2011;15:1057-66.

[22] Rahimi E, Rabiee A, Aghaei J, Muttaqi KM, Nezhad AE. On the management of wind power intermittency. Renewable and Sustainable Energy Reviews. 2013;28:643-53.

[23] Taylor M, Ralon P, Ilas A. The power to change: solar and wind cost reduction potential to 2025. International Renewable Energy Agency (IRENA). 2016.

[24] Anaya KL, Pollitt MG. Integrating distributed generation: Regulation and trends in three leading countries. Energy Policy. 2015;85:475-86.

[25] Kefayat M, Ara AL, Niaki SN. A hybrid of ant colony optimization and artificial bee colony algorithm for probabilistic optimal placement and sizing of distributed energy resources. Energy Conversion and Management. 2015;92:149-61.

[26] Viral R, Khatod D. Optimal planning of distributed generation systems in distribution system: A review. Renewable and Sustainable Energy Reviews. 2012;16:5146-65.

[27] Tan W-S, Hassan MY, Majid MS, Rahman HA. Optimal distributed renewable generation planning: A review of different approaches. Renewable and Sustainable Energy Reviews. 2013;18:626-45.

[28] Al Kaabi SS, Zeineldin H, Khadkikar V. Planning active distribution networks considering multi-DG configurations. IEEE Transactions on Power Systems. 2014;29:785-93.

[29] Javadian S, Haghifam M-R, Bathaee S, Firoozabad MF. Adaptive centralized protection scheme for distribution systems with DG using risk analysis for protective devices placement. International Journal of Electrical Power \& Energy Systems. 2013;44:337-45.

[30] Naiem A, Hegazy Y, Abdelaziz A, Elsharkawy M. A classification technique for recloser-fuse coordination in distribution systems with distributed generation. IEEE Transactions on Power Delivery. 2012;27:176-85. 
[31] Costa FB, Monti A, Paiva SC. Overcurrent protection in distribution systems with distributed generation based on the real-time boundary wavelet transform. IEEE Transactions on Power Delivery. 2017;32:462-73.

[32] Barker PP, De Mello RW. Determining the impact of distributed generation on power systems. I. Radial distribution systems. Power Engineering Society Summer Meeting, IEEE; 2000. p. 1645-56.

[33] Gomez J, Morcos M. Distributed generation: Exploitation of islanding operation advantages. Transmission and Distribution Conference and Exposition: Latin America, 2008 IEEE/PES: IEEE; 2008. p. $1-5$.

[34] Coffele F, Booth C, Dyśko A. An adaptive overcurrent protection scheme for distribution networks. IEEE Transactions on Power Delivery. 2015;30:561-8.

[35] Huchel $\iota$, Zeineldin HH. Planning the coordination of directional overcurrent relays for distribution systems considering DG. IEEE Transactions on Smart Grid. 2016;7:1642-9.

[36] Wan H, Li K, Wong K. An adaptive multiagent approach to protection relay coordination with distributed generators in industrial power distribution system. IEEE Transactions on Industry Applications. 2010;46:2118-24.

[37] Ma J, Li J, Wang Z. An adaptive distance protection scheme for distribution system with distributed generation. Critical Infrastructure (CRIS), 2010 5th International Conference on: IEEE; 2010. p. 1-4.

[38] Baran M, El-Markabi I. Adaptive over current protection for distribution feeders with distributed generators. Power Systems Conference and Exposition, IEEE PES. 2004. p. 715-9.

[39] Kumar DS, Srinivasan D, Reindl T. A Fast and Scalable Protection Scheme for Distribution Networks With Distributed Generation. IEEE Transactions on Power Delivery. 2016;31:67-75.

[40] Liu Z, Chen Z, Sun H, Hu Y. Multiagent system-based wide-area protection and control scheme against cascading events. IEEE Transactions on Power Delivery. 2015;30:1651-62.

[41] Brahma SM, Girgis AA. Development of adaptive protection scheme for distribution systems with high penetration of distributed generation. IEEE Transactions on power delivery. 2004;19:56-63.

[42] Shen S, Lin D, Wang H, Hu P, Jiang K, Lin D, et al. An Adaptive Protection Scheme for Distribution Systems With DGs Based on Optimized Thevenin Equivalent Parameters Estimation. IEEE Transactions on Power Delivery. 2017;32:411-9.

[43] Zeineldin HH, Mohamed YA-RI, Khadkikar V, Pandi VR. A protection coordination index for evaluating distributed generation impacts on protection for meshed distribution systems. IEEE Transactions on Smart Grid. 2013;4:1523-32. 
[44] Zeineldin HH, Sharaf HM, Ibrahim DK, El-Zahab EE-DA. Optimal protection coordination for meshed distribution systems with DG using dual setting directional over-current relays. IEEE Transactions on Smart Grid. 2015;6:115-23.

[45] Nikolaidis VC, Papanikolaou E, Safigianni AS. A communication-assisted overcurrent protection scheme for radial distribution systems with distributed generation. IEEE transactions on smart grid. 2016;7:114-23.

[46] Sinclair A, Finney D, Martin D, Sharma P. Distance protection in distribution systems: How it assists with integrating distributed resources. IEEE Transactions on Industry Applications. 2014;50:2186-96.

[47] Chilvers I, Jenkins N, Crossley P. Distance relaying of $11 \mathrm{kV}$ circuits to increase the installed capacity of distributed generation. IEE Proceedings-Generation, Transmission and Distribution. 2005;152:40-6.

[48] El-Khattam W, Sidhu TS. Restoration of directional overcurrent relay coordination in distributed generation systems utilizing fault current limiter. IEEE Transactions on Power Delivery. 2008;23:576-85.

[49] Yamaguchi H, Kataoka T. Current limiting characteristics of transformer type superconducting fault current limiter with shunt impedance and inductive load. IEEE Transactions on Applied Superconductivity. 2008;18:668-71.

[50] Zhang Y, Dougal RA. Novel dual-FCL connection for adding distributed generation to a power distribution utility. IEEE Transactions on Applied Superconductivity. 2011;21:2179-83.

[51] Aghdam TS, Karegar HK, Abbasi A. Discussion on "Optimal Protection Coordination for Meshed Distribution Systems With DG Using Dual Setting Relays". IEEE Transactions on Smart Grid. 2016;7:1756-1756.

[52] Saleh KA, Zeineldin H, Al-Hinai A, El-Saadany EF. Optimal coordination of directional overcurrent relays using a new time-current-voltage characteristic. IEEE Transactions on Power Delivery. 2015;30:537-44.

[53] Salem MM, Elkalashy NI, Atia Y, Kawady TA. Modified Inverter Control of Distributed Generation for Enhanced Relaying Coordination in Distribution Networks. IEEE Transactions on Power Delivery. 2017;32:78-87.

[54] Yazdanpanahi $\mathrm{H}, \mathrm{Xu} \mathrm{W}$, Li YW. A novel fault current control scheme to reduce synchronous dg's impact on protection coordination. IEEE Transactions on Power Delivery. 2014;29:542-51.

[55] Ma J, Ma W, Wang X, Wang Z. A new adaptive voltage protection scheme for distribution network with distributed generations. Canadian Journal of Electrical and Computer Engineering. 2013;36:142-51.

[56] Marchesan G, Muraro M, Cardoso G, Mariotto L, da Silva C. Method for distributed generation antiislanding protection based on singular value decomposition and linear discrimination analysis. Electric Power Systems Research. 2016;130:124-31. 
[57] Chawla A, Bhalja BR, Panigrahi BK, Singh M. Gravitational Search Based Algorithm for Optimal Coordination of Directional Overcurrent Relays Using User Defined Characteristic. Electric Power Components and Systems. 2018;46:43-55.

[58] Shabani M, Karimi A. A robust approach for coordination of directional overcurrent relays in active radial and meshed distribution networks considering uncertainties. International Transactions on Electrical Energy Systems. 2018. https://doi.org/10.1002/etep.2532

[59] Mahmud MA, Hossain MJ, Pota HR. Voltage Variation on Distribution Networks With Distributed Generation: Worst Case Scenario. IEEE Systems Journal. 2014;8:1096-103.

[60] Chiradeja P, Ramakumar R. An approach to quantify the technical benefits of distributed generation. IEEE Transactions on Energy Conversion. 2004;19:764-73.

[61] Zahedi A. Maximizing solar PV energy penetration using energy storage technology. Renewable and Sustainable Energy Reviews. 2011;15:866-70.

[62] Zahedi A. A review on feed-in tariff in Australia, what it is now and what it should be. Renewable and Sustainable Energy Reviews. 2010;14:3252-5.

[63] Mahmud N, Zahedi A. Review of control strategies for voltage regulation of the smart distribution network with high penetration of renewable distributed generation. Renewable and Sustainable Energy Reviews. 2016;64:582-95.

[64] Ruiz-Romero S, Colmenar-Santos A, Mur-Pérez F, López-Rey Á. Integration of distributed generation in the power distribution network: The need for smart grid control systems, communication and equipment for a smart city — Use cases. Renewable and Sustainable Energy Reviews. 2014;38:223-34.

[65] Bopp T, Shafiu A, Cobelo I, Chilvers I, Jenkins N, Strbac G. Commercial and technical integration of distributed generation into distribution networks. 17th International Conference on Electricity Distribution, (CIRED). 2003.

[66] Mosaddegh A, Cañizares CA, Bhattacharya K, Fan H. Distributed Computing Architecture for Optimal Control of Distribution Feeders With Smart Loads. IEEE Transactions on Smart Grid. 2017;8:1469-78.

[67] Muttaqi KM, Esmaeel Nezhad A, Aghaei J, Ganapathy V. Control issues of distribution system automation in smart grids. Renewable and Sustainable Energy Reviews. 2014;37:386-96.

[68] Antoniadou-Plytaria KE, Kouveliotis-Lysikatos IN, Georgilakis PS, Hatziargyriou ND. Distributed and Decentralized Voltage Control of Smart Distribution Networks: Models, Methods, and Future Research. IEEE Transactions on Smart Grid. 2017;8:2999-3008.

[69] El-Markabi IMS. Control and Protection for Distribution Networks with Distributed Generators. PhD Thesis. North Carolina State University; 2004. 
[70] Zhu T, Tso S, Lo K. An investigation into the OLTC effects on voltage collapse. IEEE Transactions on Power Systems. 2000;15:515-21.

[71] Echavarria R, Claudio A, Cotorogea M. Analysis, Design, and Implementation of a Fast On-Load Tap Changing Regulator. IEEE Transactions on Power Electronics. 2007;22:527-34.

[72] Hunziker C, Schulz N. Potential of solid-state transformers for grid optimization in existing lowvoltage grid environments. Electric Power Systems Research. 2017;146:124-31.

[73] Mogos EF, Guillaud X. A voltage regulation system for distributed generation. IEEE PES Power Systems Conference and Exposition, 2004. p. 787-94 vol.2.

[74] Chalise S, Atia HR, Poudel B, Tonkoski R. Impact of Active Power Curtailment of Wind Turbines Connected to Residential Feeders for Overvoltage Prevention. IEEE Transactions on Sustainable Energy. 2016;7:471-9.

[75] Ghosh S, Rahman S, Pipattanasomporn M. Distribution Voltage Regulation Through Active Power Curtailment With PV Inverters and Solar Generation Forecasts. IEEE Transactions on Sustainable Energy. $2017 ; 8: 13-22$.

[76] Zeraati M, Golshan MEH, Guerrero JM. A Consensus-Based Cooperative Control of PEV Battery and PV Active Power Curtailment for Voltage Regulation in Distribution Networks. IEEE Transactions on Smart Grid. 2017. DOI: 10.1109/TSG.2017.2749623.

[77] Su X, Masoum MAS, Wolfs PJ. Optimal PV Inverter Reactive Power Control and Real Power Curtailment to Improve Performance of Unbalanced Four-Wire LV Distribution Networks. IEEE Transactions on Sustainable Energy. 2014;5:967-77.

[78] Liu Y, Li J, Wu L. Coordinated Optimal Network Reconfiguration and Voltage Regulator/DER Control for Unbalanced Distribution Systems. IEEE Transactions on Smart Grid. 2018. DOI:

10.1109/TSG.2018.2815010.

[79] Tian Z, Wu W, Zhang B, Bose A. Mixed-integer second-order cone programing model for VAR optimisation and network reconfiguration in active distribution networks. IET Generation, Transmission \& Distribution. 2016;10:1938-46.

[80] Badran O, Mekhilef S, Mokhlis H, Dahalan W. Optimal reconfiguration of distribution system connected with distributed generations: A review of different methodologies. Renewable and Sustainable Energy Reviews. 2017;73:854-67.

[81] Hu J, Marinelli M, Coppo M, Zecchino A, Bindner HW. Coordinated voltage control of a decoupled three-phase on-load tap changer transformer and photovoltaic inverters for managing unbalanced networks. Electric Power Systems Research. 2016;131:264-74. 
[82] Kabiri R, Holmes DG, McGrath BP, Meegahapola LG. LV Grid Voltage Regulation Using Transformer Electronic Tap Changing, With PV Inverter Reactive Power Injection. IEEE Journal of Emerging and Selected Topics in Power Electronics. 2015;3:1182-92.

[83] Muttaqi KM, Le ADT, Negnevitsky M, Ledwich G. A Coordinated Voltage Control Approach for Coordination of OLTC, Voltage Regulator, and DG to Regulate Voltage in a Distribution Feeder. IEEE Transactions on Industry Applications. 2015;51:1239-48.

[84] Kraiczy M, Stetz T, Braun M. Parallel Operation of Transformers with On-load Tap Changer and Photovoltaic Systems with Reactive Power Control. IEEE Transactions on Smart Grid. 2017. DOI:

10.1109/TSG.2017.2712633.

[85] Salih SN, Chen P. On Coordinated Control of OLTC and Reactive Power Compensation for Voltage Regulation in Distribution Systems With Wind Power. IEEE Transactions on Power Systems. 2016;31:4026-35.

[86] Daratha N, Das B, Sharma J. Coordination Between OLTC and SVC for Voltage Regulation in Unbalanced Distribution System Distributed Generation. IEEE Transactions on Power Systems. 2014;29:289-99.

[87] Mehmood KK, Khan SU, Lee S-J, Haider ZM, Rafique MK, Kim C-H. A real-time optimal coordination scheme for the voltage regulation of a distribution network including an OLTC, capacitor banks, and multiple distributed energy resources. International Journal of Electrical Power \& Energy Systems. 2018;94:1-14.

[88] Zhang C, Chu X. Voltage regulation strategy for active distribution network coordinating DGs, ESS units and OLTC. 2017 IEEE Power \& Energy Society General Meeting. 2017. p. 1-5.

[89] Azzouz MA, Farag HE, El-Saadany EF. Real-Time Fuzzy Voltage Regulation for Distribution Networks Incorporating High Penetration of Renewable Sources. IEEE Systems Journal. 2017;11:1702-11.

[90] Sarimuthu CR, Ramachandaramurthy VK, Agileswari KR, Mokhlis H. A review on voltage control methods using on-load tap changer transformers for networks with renewable energy sources. Renewable and Sustainable Energy Reviews. 2016;62:1154-61.

[91] Lee TL, Hu SH, Chan YH. D-STATCOM With Positive-Sequence Admittance and Negative-Sequence Conductance to Mitigate Voltage Fluctuations in High-Level Penetration of Distributed-Generation Systems. IEEE Transactions on Industrial Electronics. 2013;60:1417-28.

[92] Zad BB, Lobry J, Vallée F. Coordinated control of on-load tap changer and D-STATCOM for voltage regulation of radial distribution systems with DG units. 2013 3rd International Conference on Electric Power and Energy Conversion Systems. 2013. p. 1-5. 
[93] Gayatri MTL, Parimi AM, Pavan Kumar AV. A review of reactive power compensation techniques in microgrids. Renewable and Sustainable Energy Reviews. 2018;81:1030-6.

[94] Kabiri R, Holmes DG, McGrath BP. The influence of pv inverter reactive power injection on grid voltage regulation. 2014 IEEE 5th International Symposium on Power Electronics for Distributed Generation Systems (PEDG). 2014. p. 1-8.

[95] Anantwar H, Lakshmikantha DBR, Sundar S. Fuzzy self tuning PI controller based inverter control for voltage regulation in off-grid hybrid power system. Energy Procedia. 2017;117:409-16.

[96] Samadi A, Eriksson R, Söder L, Rawn BG, Boemer JC. Coordinated Active Power-Dependent Voltage Regulation in Distribution Grids With PV Systems. IEEE Transactions on Power Delivery. 2014;29:145464.

[97] Collins L, Ward JK. Real and reactive power control of distributed PV inverters for overvoltage prevention and increased renewable generation hosting capacity. Renewable Energy. 2015;81:464-71.

[98] Varma RK, Khadkikar V, Seethapathy R. Nighttime Application of PV Solar Farm as STATCOM to Regulate Grid Voltage. IEEE Transactions on Energy Conversion. 2009;24:983-5.

[99] Zakariazadeh A, Homaee O, Jadid S, Siano P. A new approach for real time voltage control using demand response in an automated distribution system. Applied Energy. 2014;117:157-66.

[100] Luo X, Lee CK, Ng WM, Yan S, Chaudhuri B, Hui SYR. Use of Adaptive Thermal Storage System as Smart Load for Voltage Control and Demand Response. IEEE Transactions on Smart Grid. 2017;8:123141.

[101] Chen X, Hou Y, Tan SC, Lee CK, Hui SYR. Mitigating Voltage and Frequency Fluctuation in Microgrids Using Electric Springs. IEEE Transactions on Smart Grid. 2015;6:508-15.

[102] Luo X, Akhtar Z, Lee CK, Chaudhuri B, Tan SC, Hui SYR. Distributed Voltage Control with Electric Springs: Comparison with STATCOM. IEEE Transactions on Smart Grid. 2015;6:209-19.

[103] Yao E, Samadi P, Wong VWS, Schober R. Residential Demand Side Management Under High Penetration of Rooftop Photovoltaic Units. IEEE Transactions on Smart Grid. 2016;7:1597-608.

[104] Malík O, Havel P. Active Demand-Side Management System to Facilitate Integration of RES in LowVoltage Distribution Networks. IEEE Transactions on Sustainable Energy. 2014;5:673-81.

[105] Muttaqi KM, Aghaei J, Ganapathy V, Nezhad AE. Technical challenges for electric power industries with implementation of distribution system automation in smart grids. Renewable and Sustainable Energy Reviews. 2015;46:129-42.

[106] Sapari NM, Mokhlis H, Laghari JA, Bakar AHA, Dahalan MRM. Application of load shedding schemes for distribution network connected with distributed generation: A review. Renewable and Sustainable Energy Reviews. 2018;82:858-67. 
[107] Wang Y, Tan KT, Peng XY, So PL. Coordinated Control of Distributed Energy-Storage Systems for Voltage Regulation in Distribution Networks. IEEE Transactions on Power Delivery. 2016;31:1132-41.

[108] Nazaripouya H, Wang Y, Chu P, Pota HR, Gadh R. Optimal sizing and placement of battery energy storage in distribution system based on solar size for voltage regulation. 2015 IEEE Power \& Energy Society General Meeting. 2015. p. 1-5.

[109] Lee SJ, Kim JH, Kim CH, Kim SK, Kim ES, Kim DU, et al. Coordinated Control Algorithm for Distributed Battery Energy Storage Systems for Mitigating Voltage and Frequency Deviations. IEEE Transactions on Smart Grid. 2016;7:1713-22.

[110] Wang L, Liang DH, Crossland AF, Taylor PC, Jones D, Wade NS. Coordination of Multiple Energy Storage Units in a Low-Voltage Distribution Network. IEEE Transactions on Smart Grid. 2015;6:2906-18.

[111] Jayasekara N, Masoum MAS, Wolfs PJ. Optimal Operation of Distributed Energy Storage Systems to Improve Distribution Network Load and Generation Hosting Capability. IEEE Transactions on Sustainable Energy. 2016;7:250-61.

[112] Krishan R, Verma A, Mishra S. Voltage regulation of residential DC distribution feeder using coordinated battery energy storage units. 2017 IEEE International Conference on Smart Grid and Smart Cities (ICSGSC). 2017. p. 146-51. 